\title{
CORPORATE SOCIAL RESPONSIBILITY AND NEW TECHNOLOGIES IN FOOD INDUSTRY, THE PUBLIC PERCEPTION - CASE STUDY OF VOJVODINA
}

\author{
Tatjana Dragičević Radičevićl, Ljiljana Stanojević ${ }^{2}$, Vesna Milanović ${ }^{3}$, Zoran Katanić4, \\ Snežana Todosijević Lazovićs \\ *Corresponding author E-mail: tanjadragrad@gmail.com
}

A R T I C L E I N F O
Original Article
Received: 09 December 2019
Accepted: 08 March 2020
doi:10.5937/ekoPolj2002329D
UDC 347.72.032:338.439/.45(497.113)

Keywords:

Corporate social responsibility

- CSR, new technologies,

food, GMO, public perception,

Vojvodina

JEL: M14, O13, O33, M31

\section{A B S T R A C T}

During the past few decades many types of research have been studied Corporate Social Responsibility (CSR) but the most of these researches were focused on CSR effect on enterprise performance, but less attention has been given to the public perception of CSR and their opinions towards using new technologies, especially in food production. The purpose of this research was to investigate the public perception of CSR and their opinions regard the effect of new technologies in food production, with emphasize on genetically modified food (GMF). Empirical research was conducted in Vojvodina, as the region of Serbia, where food production is a dominant industry. The results showed that respondents mostly identify CSR with company's responsibility and moral obligation to society, especially for food production companies and recognize GMF as not offering benefits and unsafe. The trust in key actors is missing. In this regard, CSR awareness campaigns needs to be strengthened.

(C) 2020 EA. All rights reserved.

1 Tatjana Dragičević Radičević, Associate professor, University Business Academy in Novi Sad, Faculty of Applied Management, Economics and Finance, Belgrade, Јеврејска, 24/1, 11.000, Belgrade, Serbia, Phone: +381 6433444 11, E-mail: tanjadragrad@gmail.com, ORCID ID (https://orcid.org/0000-0002-5995-7347)

2 Ljiljana Stanojević, Associate professor, University Business Academy in Novi Sad, Faculty of Applied Management, Economics and Finance, Belgrade, Јеврејска, 24/1, 11.000 Belgrade, Serbia, Phone: +381 641555 049, ljstanojevic@gmail.com, ORCID ID (https://orcid.org/0000-0002-4157-4989)

3 Vesna Milanović, Full time professor, "Union - Nikola Tesla" University, Belgrade, Faculty of Business and Law, Knez Mihailova 33, 11.000, Belgrade, Serbia, Phone: +381 638864092 , E-mail: vmilanovic555@gmail.com, ORCID ID (https://orcid.org/0000-0001-8574-732X)

4 Zoran Katanić, Assistant professor, College of Professional Medical Studies "Medika", Belgrade, Serbia, Mitropolita Petra, 8, 11.000, Belgrade, Phone: +381 66130 999, E-mail: zorankatanic@yahoo.com, ORCID ID (https://orcid.org/0000-0002-7604-2931)

5 Snežana Todosijević Lazović, Associate professor, University of Priština, Faculty of Economics Mitrovica, Serbia, Kolašinska, 156, 38220 Kosovska Mitrovica, Phone: +381 63533 625, E-mail: snežana.todosijevic1@hotmail.com, ORCID ID (https://orcid.org/0000-0001-9102-6123)

http://ea.bg.ac.rs 


\section{Introduction}

Corporate Social Responsibility (CSR) is the concept which interests the scientist, business people, and public for over 50 years. The first concept emphasized CSR through environmental protection, but today it is obvious that CSR concept is a multidisciplinary, various and very complex.

The issues linked to CSR have become an important driver of public opinion from the beginning of the 90th years of 20 century. According to Pfau et al. (2008, p. 145), CSR “campaigns enhanced people's perceptions of sponsors' image, reputation, and credibility“. However, a smaller number of empirical research has focused especially on the influence of CSR campaigns on public opinion, especially in the agribusiness sector. At the same time, CSR is of high relevance for food companies as this sector has a strong influence on society.

New technologies are taking over the world, and food industry is not immune to this. The use of new technologies in food production is not publicly well understand and accepted, but rather considered as a source of potential risk. Furthermore, producers are focused on the new food technologies (especially GMO), because GMO is important in food production.

The purpose of this research was to investigate the public perception of CSR and their opinions regard the effect and use of new technologies in food production, with emphasize on GM food in the region of Vojvodina. Vojvodina is the region in Serbia of mainly food production developed branches. Therefore, the aim of the paper was to present CSR towards using new technologies in food production from the point of view perception of the public - case study of Vojvodina.

\section{Theoretical Framework}

CSR is a multidimensional, multilevel, interdisciplinary, integrative approach. According to Broomhill (2007, p. 6-7), three approaches about SCR can be found in the literature: neoliberal, neo-Keynesian and radical political economy. According to neoliberal approach fundamentally is to create and adopt the set of policies, codes, guidelines in the corporation. This approach considers Fridman's view, gaining the profit and stay within the defined rules. The neo-Keynesian approach is more complex than neoliberal approach. It recognizes the active role of the corporation's stakeholders and state. This approach put much more attention on corporate behaviors and state role in developing the CSR regulations and practice. Nevertheless, this CSR approach involves voluntariness without external regulation (see: EC, 2001). The radical political economy approach emphasizes the presence of three level with a great interaction of CSR. Those levels are global, national and local economies. It also considers the efficiency of CSR regarding its voluntary, no obligation form. In this regard, radical political analysts are "concerned that self-regulatory and voluntary CSR policies are frequently deliberately designed by corporations" to legitimate some "activities that are socially and environmentally destructive" (Broomhill, 2007, p. 8). This approaches 
open the question about the "what is the precise definition of CSR?" This question is also arises by Carroll (1998). Carroll (1998, p. 2) considers that significant approach about CSR raised at the end 90th years of XX century when profit-making activities extended also to the performances such as four faces of good corporate citizens are: "Be profitable (carry their own weight or fulfill their economic responsibilities); Obey the law (fulfill their legal responsibilities); Engage in ethical behavior (be responsive to their ethical responsibilities); Give back through philanthropy (engage in corporate contributions)." In this regard, organizations should contribute to the wellbeing of the society (Pfau et al., 2008).

Aguinis and Glavas (2012) wrote the article also inquiring the meaning of CSR. The article was based on author's literature review of 588 journal articles and 102 books. The intent was to create the theoretical framework of different definitions, approaches, measures, variables etc. of CSR. Their conclusions are as follows: interest in CSR is rising, organizations are increasingly involved in CSR, an audience interested in CSR is very wide, it is integrative and complex scientific and practice concept, CSR has a multilevel approach.

Besides, CSR importance is notable as the concept with the great concern in international institutions such as United Nations (UN), European Union (EU) etc. UN Global compact launched in 2000, emphasizes the ten universal principles in the area of human rights, environment, labor and anti-corruption as the main goal in business activities (United Nations Global Compact, 2017). European Commission in Green Paper - "Promoting a European framework for CSR 2001" (EU, 2017) and in "A renewed EU strategy for CSR" (EUR Lex, 2011) emphasizes that the importance of CSR today is greater than ever. It is clear how CSR is important in today's business environment, especially in agribusiness.

At the same time, CSR in agribusiness is facing a lot of challenges and conflicts. Agriculture is one of the economic branches with arising innovation in production, especially food production. Perception of those new technologies are various, from expectancy to not just refusal, but the strong campaign against it. Producers are defending the new food technologies (primarily considering GMO), the scientist is confronted, and the public is confused. But as the most common problem can be defined as the lack of information and not understandings the new technologies in food production, so the choice can be made. Besides, according to Heyder and Theuvsen (2009), consumers have no trust in the food industry, despite all the certifications, standards and etc. Also, public opinion is mostly neglected, the supply chain is not transparent, general social issues are not considered, in one word there is too much not understanding (justified or not justified). In this regard, Heyder and Theuvsen see the CSR as the response to mentioned problems and emphasized the Carroll model of four faces CSR (1988). However, research of Heyder and Theuvsen (2009, p. 10) shows that "altruistic firms" accepted the CSR concept are small and specialized in organic production; "Strategist" is focused on increasing the market share and not regarding public pressure; "Criticized firms" implementing CSR based on pressure. The findings by Luhmann and Theuvsen (2017, p. 241) reveal that "Carroll's model, which was developed from a U.S. point of http://ea.bg.ac.rs 
view, cannot be confirmed for German agribusiness." Thus, the areas of responsibility are: economic, internal and external (Luhmann, Theuvsen, 2017).

Many previous studies are focused on examining the link between CSR and financial performance (see: Pfau et al., 2008, p. 145; Omidi et al., 2018) as well as between CSR and corporate identity (Salleh et al., 2013). Besides, CSR is an important issue in the marketing literature which is focused on different topics such as: consumer's attitudes to CSR and Green marketing (Čerkasov et al., 2017); relationship between CSR practices, corporate identity and purchase intention (Prabu et al., 2005); the influence of CSR on customer loyalty (Iglesias et al., 2018); CSR and consumer buying behavior (Brown, Dacin, 1997; Chai et al., 2015; Civero et al., 2017; Webster, 1975); perception of CSR and purchase intention of consumers (Mohr, Webb, 2005); consumers' perception of CSR, e.g. consumer survey in France, Germany, the U.S. (Maignan, 2001), and in China (Tian et al., 2011); consumers' perception of the impact of CSR in fast-food restaurants, Hong Kong (Tong et al., 2019); consumer responses to CSR (Sankar, Bhattacharya, 2001); public perception of CSR (Chai et al., 2015); influence of CSR campaigns on public opinion (Pfau et al., 2008); CSR and public opinion (Vallentin, 2004).

According to Luhmann and Theuvsen (2016, p. 673), "The spotlight of public attention has only recently come to focus on agribusiness-related aspects of CSR." In this regard, some studies are focused on public opinion toward GMO (Rzymski, Królczyk, 2016), public opinion toward agricultural biotechnology (Malyska et al., 2016), public opinion of GMO and biotechnology (Bevanda et al., 2017), CSR and consumer attitudes or public perceptions toward GMF - genetically modified foods (Cui, Shoemaker, 2018; Pino et al., 2016), etc. In this regard, the findings of empirical research on CSR in agribusiness (Germany) show that the enterprises perceived high public pressure, especially towards GMOs i.e. the public opinion is high considering this production as a potential health risk, environmental externalities of production processes, harmful, contaminate (Heyder, Theuvsen 2009, p. 9). Less attention has been given to the public perceptions of CSR in agribusiness and their opinions towards using new technologies, especially in food production such as GMO.

\section{Research Methodology}

The empirical research was conducted using a questionnaire as an instrument in the Vojvodina. Survey was conducted exclusively with the aim of obtaining relevant public opinion information regarding knowledge about CSR, development and using of a new technologies in food production and GMO-related considerations. Similar research was carried out in the EU countries in 2010 by the European Commission (EC, 2010). Most of the questions from the survey questionnaire were taken from the above research (EC, 2010) and marked * in order to be able to compare the obtained results (Vojvodina, the Republic of Serbia - EU27) and to make relevant conclusions on the matching and deviations in the public opinion regarding the given topic.

To evaluate the public perception a questionnaire was made. The first part of the 
questionnaire is a demographics survey (see: Table 1).

The second part of the questionnaire investigates the public perception of CSR. It contains a series of close-ended questions: Do you know what CSR is? Whether CSR relates solely to advertising spots and humanitarian actions of companies? Whether the company that produces GM foods and does not visually mark its products with a special label (but instead use small letters), is considered socially responsible? The following answers are offered: 1 - "yes", 2 - "no", 3 - "maybe". In addition, the questionnaire contains two open-ended questions: "Try to define what is CSR for you?" as well as "Try to define what is CSR for food companies?"

The third part of the questionnaire investigates public attitudes towards new technologies with special emphasis on using new technologies in food production and GM food, whether their attitudes are positive, negative, or neutral. As a new technologies, solar energy, computers and IT, biotechnology and genetic engineering, space exploration, nuclear energy, nanotechnology, wind energy and brain and cognitive enhancement were observed. According to the similar research conducting in the EU (EC, 2010), these technologies are considered as 'sensitive' technologies because public opinions toward their using could awake various emotions in spite of their technical characteristics and economic implications. For these eight technologies, it was investigated what respondents think about their influence on lives, whether they have positive, negative or no effect. At the same time, the evaluation of public attitudes towards new technologies in food production and GM food was based on Likert-type scale. Questions (according to EC, 2010) provided the answers for GM benefits, un/fairness, understanding the GM technology, risks and worries. Besides, every scientific and technological innovation include some kind of risk and uncertainty. That is why thrust in key actors play an important role in accepting new technologies. In this regard, the third part of the survey included questions (according EC, 2010) related to the trust in key actors, whether they are doing or not doing a good job for society? The statement "doing a good job for society" was used as a measure of trust and confidence as it expressed the view that the actor is both competent and behaves in a socially responsible way.

The methods used were descriptive statistics and correlation analysis (adopted to Chai et al., 2015) as well as comparative analysis.

The data were collected through personally survey. The survey was conducted from May until December 2014 in the regions of Vojvodina. Random sampling was adopted. At the same time, the survey limits the age of research objects not to be less than 18 years old. At last, the total sample included 172 respondents. The results of the sample structure are shown in Table 1 (the first part of the questionnaire). 
Table 1. The sample structure

\begin{tabular}{|c|c|c|}
\hline Variable & Attribute & $(\%)$ \\
\hline \multirow{3}{*}{ Gender } & Male & 31 \\
\hline & Female & 69 \\
\hline & $\Sigma$ & 100 \\
\hline \multirow{5}{*}{ Highest education } & Elementary school & 2 \\
\hline & High school & 79 \\
\hline & Bachelor degree & 8 \\
\hline & University degree & 11 \\
\hline & $\Sigma$ & 100 \\
\hline \multirow{4}{*}{ Regions } & Backa & 68 \\
\hline & Srem & 12 \\
\hline & Banat & 20 \\
\hline & $\Sigma$ & 100 \\
\hline \multirow{3}{*}{ Religious or atheist } & Religious & 87 \\
\hline & Atheist & 13 \\
\hline & $\Sigma$ & 100 \\
\hline \multirow{7}{*}{ Occupation } & Student & 54 \\
\hline & Retiree & 7 \\
\hline & Lawyer/economist & 12 \\
\hline & Doctor / Pharm./Biolog./ Ecolog. & 2 \\
\hline & Engineer & 1 \\
\hline & Other & 24 \\
\hline & $\Sigma$ & 100 \\
\hline
\end{tabular}

\section{Results and discussions}

The results of the second part (investigates the public perception of CSR) were presented in Table 2, Table 3 and Table 4.

When asked "Do you know what CSR is?", 73\% of respondents answered "yes", compared to $25 \%$ who answered "no" ( $2 \%$ of respondents answered "maybe"). Among those who answered "yes", 71\% of them defined CSR as a company's responsibility towards society, while $25 \%$ answered that the term refers to environmental protection (4\% answered that the term refers to philanthropy and similary. Also, 36\% of respondents identified CSR of the food production companies with a moral obligation to society, health and the environment, and $35 \%$ of them with consumer protection, individual and healthy foods. Furthermore, the results have shown that education, occupation, and religion did not have a significant influence on public awareness of CSR, while gender had (Table 2).

Table 2. Public awareness of CSR - the influence of demographic variables

\begin{tabular}{|l|l|c|c|c|c|}
\hline Question & Corr/Variable & Gender & Education & Occupation & Religion \\
\hline \multirow{2}{*}{$\begin{array}{l}\text { Do you know } \\
\text { what CSR is? }\end{array}$} & Pearson Correl. &, $228^{* *}$ &, 027 &, 053 &, 056 \\
\cline { 2 - 6 } & Sig. &, 003 &, 727 &, 488 &, 467 \\
\cline { 2 - 6 } & $\mathrm{N}$ & 172 & 172 & 172 & 172 \\
\hline ** Correlation is significant at the 0.01 level (2-tailed). \\
\hline
\end{tabular}

Source: Authors' calculations 
Female respondents had the higher CSR awareness (61\%) than male respondents (39\%) in Vojvodina. For example, female respondents (consumers in Chine) knew less about CSR than male respondents. However, the satisfaction degree with the enterprise undertaking of CSR of female consumers was higher than male respondents (Chai et al., 2015). At the same time, possible reasons for "negative correlation between the satisfaction degree of enterprise undertaking of CSR and education background may be as follows: the higher the education level of the consumers, the more attention will be paid on the knowledge accumulation and updating, which reflects on the more attention to the enterprise undertaking of CSR" (Chai et al., 2015). It means that a lack of information leads to an inadequate understanding CSR of enterprise.

According to Table 3, respondents were aware that CSR is not related solely to advertising spots and humanitarian actions of companies and that the company that produces GM foods, and does not visually mark its products with a special label, is not considered socially responsible.

Table 3. Public opinion toward CSR - Descriptive statistics

\begin{tabular}{|l|c|c|c|c|}
\hline Questions & Min. & Max. & Mean & St. Dev. \\
\hline $\begin{array}{l}\text { Whether CSR relates solely to advertising spots and } \\
\text { humanitarian actions of companies? }\end{array}$ & 1 & 3 & 2,21 &, 595 \\
\hline $\begin{array}{l}\text { Whether the company that produces GM foods and does not } \\
\text { visually mark its products with a special label (but instead use } \\
\text { small letters), is considered socially responsible? }\end{array}$ & 1 & 3 & 1,80 &, 573 \\
\hline 1-yes, 2-no, 3-maybe & & & \\
\hline
\end{tabular}

Source: Authors' calculations

Public opinion toward CSR - the influence of demographic variables was presented in Table 4.

Table 4. Public opinion toward CSR - the influence of demographic variables

\begin{tabular}{|l|l|c|c|c|c|}
\hline Questions & Corr/Variable & Gender & Education & Occupation & Religion \\
\hline $\begin{array}{l}\text { Whether CSR relates solely } \\
\text { to advert. spots and humanit. } \\
\text { actions of comp.? }\end{array}$ & Pearson Correl. &,- 015 &,$- 206^{* *}$ &, 037 &, 063 \\
\cline { 2 - 6 } & Sig. (2-tailed) &, 848 &, 007 &, 632 &, 412 \\
\cline { 2 - 6 } & $\mathrm{N}$ & 172 & 172 & 172 & 172 \\
\hline $\begin{array}{l}\text { Whether the company that } \\
\text { produces GM foods and } \\
\text { does not visually mark its } \\
\text { products with a special } \\
\text { label (but instead use small } \\
\text { letters), is considered } \\
\text { socially responsible? }\end{array}$ & Pearson Correl. &, $158^{*}$ &, 092 &,- 149 &,- 009 \\
\cline { 2 - 6 } & Sig. (2-tailed) &, 039 &, 229 &, 052 &, 909 \\
\cline { 2 - 6 } $\begin{array}{l}* \text { Correlation is significant at the 0.05 level (2-tailed); ** Correlation is significant at the 0.01 level } \\
\text { (2-tailed) }\end{array}$ & 172 & 172 & 172 & 172 \\
\hline
\end{tabular}

Source: Authors' calculations 
Results also revealed that respondents with higher education level tend to recognize CSR through advertising spots and humanitarian actions of companies more often than those with lower education level (the correlation is negative). Furthermore, gender had a significant impact on respondents' attitudes about labeling GM foods and CSR of producer of GM foods (Table 4).

The first results of the third part (investigates public attitudes towards new technologies with special emphasis on using new technologies in food production and GM food) are represented in Table 5 and Figure 1.

Table 5. *Opinions of new technology - Descriptive statistics

\begin{tabular}{|l|c|c|}
\hline New technologies & Mean & Std. Deviation \\
\hline Solar energy & $1,36^{* *}$ &, 891 \\
\hline Computers and IT & $1,52^{* *}$ &, 921 \\
\hline Biotechnology and genetic engineering & 2,19 & 1,171 \\
\hline Space exploration & 2,15 & 1,260 \\
\hline Nuclear energy & 2,22 &, 960 \\
\hline Nanotechnology & 2,55 & 1,356 \\
\hline Wind energy & $1,51^{* *}$ & 1,006 \\
\hline Brain and cognitive enhancement & $1,66^{* *}$ & 1,141 \\
\hline 1-Positive effect**, 2-No effect, 3-Negative effect \\
\hline
\end{tabular}

Source: Authors' calculations

Figure 1.*Optimism and pessimism regarding eight technologies in Vojvodina

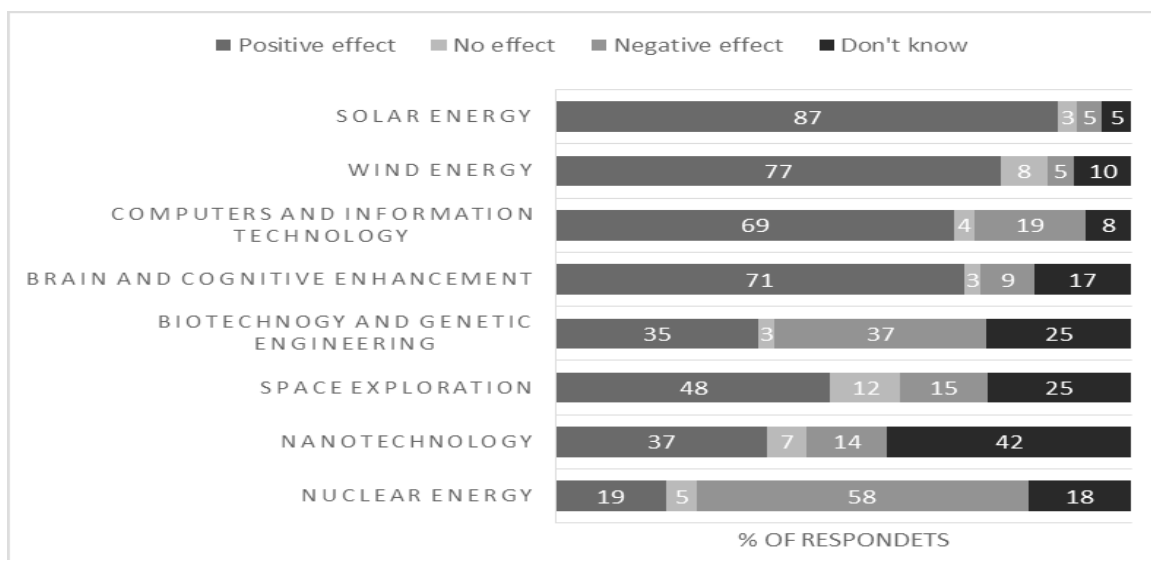

Source: Authors' calculations

According to the results represented in Table 4 and Figure 1 have shown that for four out of the eight technologies optimists outnumbered pessimists (positive effect vs. negative effect). Exceptions are biotechnology and genetic engineering and nuclear power. While positive and negative expectations about biotechnology and genetic engineering are nearly equal, expectations regarding nuclear energy are the expectations with an obvious pessimism. For nanotechnology, as new once, the percentage of 'don't know' 
responses was high. Biotechnology, space exploration, nuclear energy, and brain and cognitive enhancement were probably relatively unfamiliar to many of the public (see: 'don't know' response). Yet the idea of this technology seems to engender widespread optimism, with optimists outnumbering pessimists by a ratio of 7 to 1 . Nuclear power had the most negative opinions. The percentage of Europeans saying 'it will improve our way of life' was 39\% (Figure 2) comparing to 19\% in Vojvodina (Figure 1).

Europeans had a similar attitude towards the effect of biotechnology, computers, and nanotechnology. The main difference results in attitude towards nuclear energy as percentages of optimists and pessimists Europeans are equal (Figure 2).

Figure 2.*Optimism and pessimism regarding eight technologies in EU27

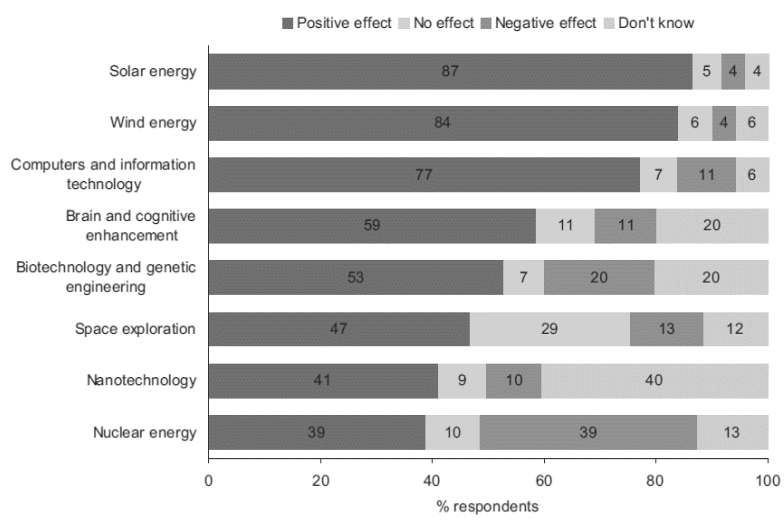

Source: EC (2010, p.16)

Comparing to Europeans attitudes (Figure 2), respondents in Vojvodina (Figure 1) were more optimistic regarding brain and cognitive technologies, but less optimistic regarding computers and information technologies and wind energy, and had equal optimism regarding the use of solar energy and space exploration. Overall optimism and pessimism in Vojvodina and EU regarding the eight technologies are shown in Figure 3. Europeans are more optimistic and less pessimistic than respondents in Vojvodina.

Figure 3. * Optimism and pessimism regarding eight technologies in EU27 and Vojvodina

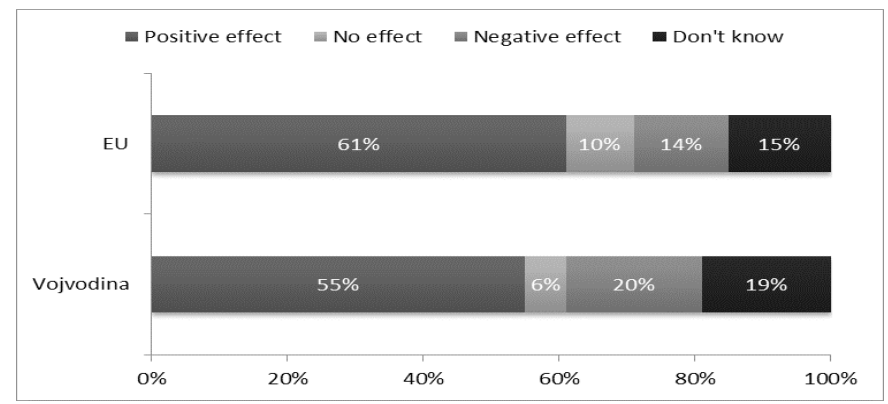

Source: Authors' calculations; EC (2010, p. 16, adopting to Figure 2) 
The second results of the third part (about GM food) are represented in Figure 4, Figure 5, Table 6 and Figure 6. Figure 4 and Figure 5 show awareness of GM food in Vojvodina and EU27. The majority of respondents in Vojvodina and in EU27 were familiar with GM food. It is clear that public attention of GM in Vojvodina was higher than in EU 27.

Figure 4.* Awareness of GM food in Vojvodina

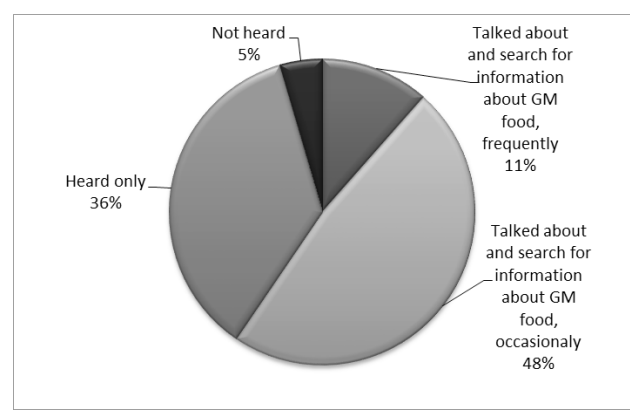

Source: Authors' calculations

\section{Figure 5.* Awareness of GM food in EU27}

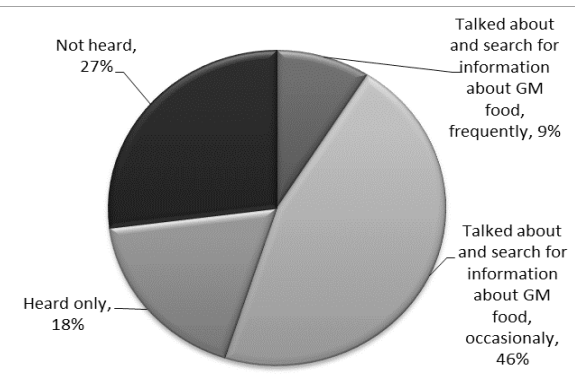

Source: EC (2010, p. 37, according to Figure 12)

The results of this survey (respondent attitudes regards GM food) are presented in Table 6. To explore what influencing on public attitudes regards GM food, a five Likerttype survey was created.

Table 6.*Respondents attitudes regards GM food - Descriptive statistics

\begin{tabular}{|l|c|c|}
\hline Questions (according to EC, 2010, p. 113) & Mean & Std. Deviat. \\
\hline GM food is good for the (nationality) economy & 3,80 &, 809 \\
\hline GM food is not good for you and your family & 3,71 &, 947 \\
\hline GM food helps people in developing countries & 3,69 &, 969 \\
\hline GM food is safe for future generations & 2,97 & 1,661 \\
\hline GM food benefits some people but puts others at risk & 2,26 & 1,449 \\
\hline GM food is fundamentally unnatural & 3,41 & 1,363 \\
\hline GM food makes you feel uneasy & 1,81 &, 854 \\
\hline GM food is safe for your health and your family's health & 3,58 & 1,134 \\
\hline GM food does no harm to the environment & 2,19 & 1,369 \\
\hline GM food should be encouraged & 3,37 & 1,200 \\
\hline 1-totally agree, 2-tend to agree, 3-tend to disagree, 4-totally disagree
\end{tabular}

Source: Authors' calculations

The results have shown that the respondents in Vojvodina saw GM food as a solution that is not good for economy nor it could help people in developing countries. Besides, GM food was recognized as an unnatural and not healthy food that can be harmful to future generations as well as for our environment (Table 6). This finding is consistent with the finding of Heyder and Theuvsen (2009, p. 9). Similarly, the survey by Cui and Shoemaker (2018) showed that $41.4 \%$ of respondents in China had a neutral view on GM food while $46.7 \%$ of them had a negative view on GM food. Thus, a minority of 
respondents had a positive view. Combining 'totally agree' and 'tend to agree', percent in support for GM food in Vojvodina was almost equal to the percentage in EU (Figure 6). Furthermore, the greater percent of respondent in Vojvodina and in EU 27 was not willing to support GM food.

Figure 6. Support for GM food in EU and Vojvodina

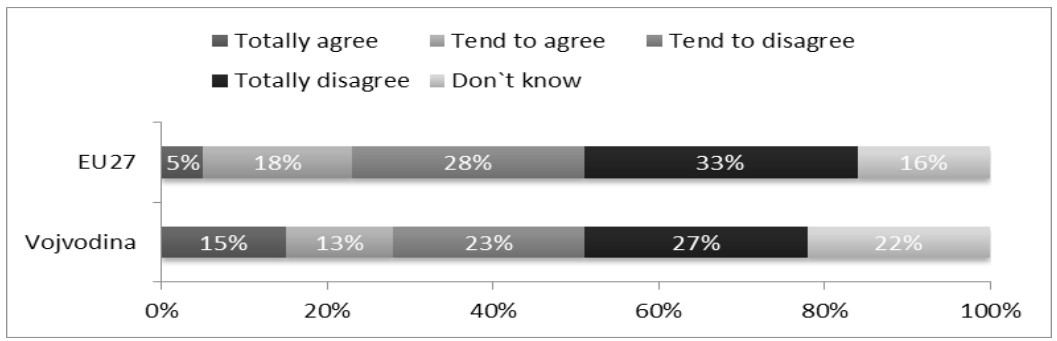

Source: Authors' calculations; EC (2010, p. 37, according to Figure 13)

The results of the third part of the survey - questions related to the trust in key actors are represented in Table 7. Newspapers and magazines, university scientists, environmental groups and consumer organizations attracted the confidence between $50 \%$ and $65 \%$ of respondents from Vojvodina. All others attracted confidence below 50\%. Contrary that, all actors attracted confidence above $50 \%$ of respondents from EU. For all actors, except newspapers and magazines, the percentage of 'do not know' responses in Vojvodina was higher than in the EU.

Table 7.*Trust in key actors

\begin{tabular}{|l|c|c|c|c|c|c|}
\hline \multirow{2}{*}{ Key actors } & \multicolumn{3}{|c|}{ EU27 } & \multicolumn{3}{|c|}{ Vojvodina } \\
\cline { 2 - 7 } & $\begin{array}{c}\text { Dooing a } \\
\text { godob for } \\
\text { society }\end{array}$ & $\begin{array}{c}\text { Not doing } \\
\text { a good } \\
\text { job }\end{array}$ & $\begin{array}{c}\text { Don't } \\
\text { know }\end{array}$ & $\begin{array}{c}\text { Doing a } \\
\text { good job for } \\
\text { society }\end{array}$ & $\begin{array}{c}\text { Not doing } \\
\text { a good } \\
\text { job }\end{array}$ & $\begin{array}{c}\text { Don't } \\
\text { know }\end{array}$ \\
\hline $\begin{array}{l}\text { Medical doctors keeping } \\
\text { an eye on the health } \\
\text { implications of biotech. }\end{array}$ & $78 \%$ & $8 \%$ & $14 \%$ & $39 \%$ & $23 \%$ & $38 \%$ \\
\hline $\begin{array}{l}\text { University scientists doing } \\
\text { research in biotech. }\end{array}$ & $74 \%$ & $8 \%$ & $18 \%$ & $59 \%$ & $14 \%$ & $27 \%$ \\
\hline $\begin{array}{l}\text { Consumer organizations } \\
\text { checking products of } \\
\text { biotech. }\end{array}$ & $70 \%$ & $11 \%$ & $19 \%$ & $51 \%$ & $23 \%$ & $26 \%$ \\
\hline $\begin{array}{l}\text { Newspapers and magazines } \\
\text { reporting on biotech. }\end{array}$ & $62 \%$ & $20 \%$ & $18 \%$ & $63 \%$ & $22 \%$ & $15 \%$ \\
\hline $\begin{array}{l}\text { Industry developing new } \\
\text { products with biotech. }\end{array}$ & $56 \%$ & $19 \%$ & $25 \%$ & $29 \%$ & $33 \%$ & $38 \%$ \\
\hline $\begin{array}{l}\text { Environmental groups } \\
\text { campaigning against biotech. }\end{array}$ & $63 \%$ & $15 \%$ & $22 \%$ & $55 \%$ & $17 \%$ & $28 \%$ \\
\hline $\begin{array}{l}\text { Our government in making } \\
\text { regulations on biotech. }\end{array}$ & $54 \%$ & $20 \%$ & $26 \%$ & $45 \%$ & $24 \%$ & $31 \%$ \\
\hline $\begin{array}{l}\text { Shops making sure our food } \\
\text { is safe }\end{array}$ & $59 \%$ & $22 \%$ & $19 \%$ & $12 \%$ & $66 \%$ & $22 \%$ \\
\hline
\end{tabular}

Source: Authors' calculations; EC (2010, p. 76, according to Table 9) 


\section{Conclusions}

In the previous studies, less attention has been given to the public perceptions of CSR in agribusiness and their opinions towards using new technologies, especially in food production such as GMO. In this regard, the survey was conducted in Vojvodina as the region in Serbia of mainly food production developed branches. The research can be significant in terms of information and scientific observations in the creation of future frameworks in the issues of CSR and GMO in Vojvodina (the Republic of Serbia).

The results of the empirical research have shown that: (1) the majority of respondents know what CSR is (2) they mostly define CSR as a company's responsibility to society, and CSR of food companies as a moral obligation of company. Generally, respondents are aware that CSR is more than advertising and philanthropy as well as that GM foods should be marked with a special label. If the company does not visually mark its GM foods with a special label is not socially responsible. In this regard, it is necessary to strengthen awareness campaigns about link between CSR of food companies with a healthy product without GM.

Besides, the results have shown:(1) gender has a significant influence on public awareness of CSR and on labeling of GM foods as an obligation of company (2) education has a significant influence on recognize CSR through advertising spots and humanitarian actions. According to the results, awareness campaigns of CSR and labeling of GM foods need to be strengthened, especially for males, as well as campaigns to recognize CSR through advertising spots and humanitarian actions of companies, especially for respondents with lower education.

Regarding the new technologies, the results have shown: (1) the respondents in Vojvodina are more pessimistic and less optimistic than Europeans (2) expectations regarding nuclear energy are the expectations with an obvious pessimism (3) many new technologies are relatively unfamiliar to many of the public, especially nanotechnology and biotechnology. According to the results, it needs to strengthen awareness campaigns about that nuclear power may improve our way of life and the campaigns aimed at informing and education about nanotechnology and biotechnology, benefits and potential negative effects.

Besides, the results have shown: (1) the majority of respondents in Vojvodina and EU are familiar with GM food (2) the respondents in Vojvodina saw GM food as not offering benefits, as unsafe, as inequitable and as worrying (3) the comparison between Vojvodina and EU has shown no substantial difference in the public perception of GM food (the dimension that most differentiates supporters and opponents is the issue of safety and benefit and worry). In this regard, it is necessary to increase a level of the knowledge in the public of GM food.

Key actors play an important role in accepting new technologies, however, comparing to Europeans: (1) respondents in Vojvodina are more pessimist and they do not have confidence in the key actors (2) lack of trust in key actors may be the reason why 
respondents in Vojvodina in the great majority think that it is up to people to seek out the benefits from new technologies themselves. The great problem is a lack of information and not understanding the new technologies in food production. The government should take responsibility to ensure that new technologies benefit everyone.

The research can be significant in terms of information and observations in the creation of future frameworks in the issues of CSR and GMO in the Republic of Serbia. We recommend to repeat the research but after the EU conduct the new research in this area so we can compare the new results.

\section{Acknowledgements}

This paper is supported by Ministry of Education, Science and Technological Development of the Republic of Serbia, project iii 45003 - „Nano-scale Optoelectronic Systems - Towards its application”, Institute of Physics Belgrade (2011-).

\section{Conflict of interests}

The authors declare no conflict of interest.

\section{References}

1. Aguinis, H., \& Glavas, A. (2012). What We Know and Don't Know About Corporate Social Responsibility: A Review and Research Agenda. Journal of Management, 38(4), 932-968.

2. Bevanda, L., Žilić, M., Ećimović, B., \& Matković, V. (2017). Public opinion toward GMOs and biotechnology in Bosnia and Herzegovina. International Conference on Medical and Biological Engineering. In: Badnjevic A. (ed) CMBEBIH 2017. IFMBE Proceedings, 62. Springer, Singapore, 452-458.

3. Broomhill, R. (2007). Corporate Social Responsibility: Key issues and Debates. Dunstan papers, 1. Published Adelaide, Don Dunstan Foundation, SA.

4. Brown, J. T., \& Dacin, A. P. (1997). The company and the product: Corporate associations and consumer product responses. Journal of Marketing, 61(1), 68-84.

5. Carroll, B. A. (1998). The Four Faces of Corporate Citizenship. Business and Society Review, 100(1), 1-7.

6. Chai, J., Chang, P., Wang, Z., \& Brew, Y. (2015). The public perception of corporate social responsibility and its effects on customer behavior in China. American Journal of Industrial and Business Management, 5(10), 611-621.

7. Civero, G., Rusciano, V., \& Scarpato, D. (2017). Consumer behaviour and corporate social responsibility: an empirical study of Expo 2015. British Food Journal, 119(8), pp. 1826-1838.

8. Cui, K., \& Shoemaker, S. P. (2018). Public perception of genetically-modified (GM) food: a nationwide Chinese consumer study. npj Science of Food, 2(1), 1-8. 
9. Čerkasov, J., Huml, J., Vokáčová, L., \& Margarisová, K. (2017). Consumer’s attitudes to corporate social responsibility and green marketing. Acta Universitatis Agriculturae et Silviculturae Mendelianae Brunensis, 65(6), 1865-1872.

10. EC - European Commission (2001). Promoting a European Framework for Corporate Social Responsibility. Green paper. Office for Official Publications of the European Commission, Luxembourg.

11. EC - European Commission (2010). Europeans and Biotechnology in 2010, Winds of change? Publications Office of the European Union, Luxembourg, Retrieved from https:/ec.europa.eu/research/swafs/pdf/pub_archive/europeansbiotechnology-in-2010 en.pdf (July, 6 2017)

12. EU - The European Union green paper on CSR, 2017, Retrieved from https:// www.iisd.org/business/issues/eu_green_paper.aspx (July, 6 2017)

13. EUR Lex (2011). Communication from the commission to the European parliament, the council, the European economic and social committee and the committee of the regions, A renewed EU strategy 2011-14 for Corporate Social Responsibility, Retrieved from http:/eur-lex.europa.eu/legal-content/EN/ TXT/?uri=CELEX:52011DC0681 (July, 6 2017)

14. Heyder, M., \& Theuvsen L. (2009). Corporate Social Responsibility in Agribusiness: Empirical Findings from Germany, 113th EAAE Seminar - A resilient European food industry and food chain in a challenging world (Greece, September 3-6, 2009). European Association of Agricultural Economists, Retrieved from https:// ageconsearch.umn.edu/record/58152 (July, 6 2017)

15. Iglesias, O., Markovic, S., Bagherzadeh, M., \& Singh, J. J. (2018). Co-creation: A key link between corporate social responsibility, customer trust, and customer loyalty. Journal of Business Ethics, 1-16. Available at: https://doi.org/10.1007/ s10551-018-4015-y

16. Luhmann, H., Theuvsen, L. (2016). Corporate Social Responsibility in Agribusiness: Literature Review and Future Research Directions. Journal of Agricultural and Environmental Ethics, 29(4), 673-696.

17. Luhmann, H., \& Theuvsen, L. (2017). Corporate social responsibility: exploring a framework for the agribusiness sector. Journal of Agricultural and Environmental Ethics, 30(2), 241-253.

18. Maignan, I. (2001). Consumers' perceptions of corporate social responsibilities: A cross-cultural comparison. Journal of Business Ethics, 30(1), 57-72.

19. Malyska, A., Bolla, R., \& Twardowski, T. (2016). The role of public opinion in shaping trajectories of agricultural biotechnology. Trends in Biotechnology, 34(7), 530-534.

20. Mohr, L.A., \& Webb, D.J. (2005). The Effects of Corporate Social Responsibility and Price on Consumer Responses. Journal of Consumer Affairs, 39, 121-147. 
21. Omidi, F., \& Shafiee, M. M. (2018). The impact of corporate social responsibility on social performance, financial performance and customer reactions in the food industry. International Journal of Business Innovation and Research, 17(2), 249-265.

22. Pino, G., Amatulli, C., De Angelis, M., \& Peluso, A. M. (2016). The influence of corporate social responsibility on consumers' attitudes and intentions toward genetically modified foods: evidence from Italy. Journal of cleaner production, 112, 2861-2869.

23. Pfau, M., Haigh, M.M., Sims, J., \& Wigley, S. (2008). The Influence of Corporate Social Responsibility Campaigns on Public Opinion. Corporate Reputation Review, 11(2), 145-154.

24. Prabu, D., Kline, S., \& Yang D. (2005). Corporate social responsibility practices, corporate identity, and purchase intention: a dual-process model. Journal of Public Relations Research, 17(3), 291-313.

25. Rzymski, P., \& Królczyk, A. (2016). Attitudes toward genetically modified organisms in Poland: to GMO or not to GMO? Food Security, 8(3), 689-697.

26. Salleh, M. M., Wahid, N. A., \& Marimuthu, M. (2013). Corporate Social Responsibility to Reflect Organization's Corporate Identity: A Content Analysis. Journal of Economics, Business and Management, 1(1), 98-101.

27. Sankar, S., \& Bhattacharya, C. B. (2001). Does doing good always lead to doing better? Consumer reactions to corporate social responsibility. Journal of Marketing Research, 38(2), 225-243.

28. Tian, Z., Wang, R., \& Yang, W. (2011). Consumer responses to corporate social responsibility (CSR) in China. Journal of Business Ethics, 101(2), 197-212.

29. Tong, C., Wong, A. T. T., \& Cheng, T. (2019). Do Corporate Social Responsibility and Safety of Food Affect Reputation? A Study of Fast-food Restaurants Industry in Hong Kong. Journal of Economics, Management and Trade, 22(3), 1-18.

30. UN - United Nations Global Compact, Retrieved from http://www.csrwire.com/ members/12044-united-nations-global-compact (July, 6 2017)

31. Vallentin, S. (2004). Corporate social responsibility and public opinion. The 6th International Conference on Corporate Reputation, Identity and Competitiveness, 2002, Boston, MA, US, Retrieved from http://195.130.87.21:8080/dspace/ bitstream/123456789/299/1/Vallentin-corporate\%20social\%20responsibility\%20 and\%20public\%20opinion.pdf (January 7, 2019)

32. Webster Jr., F. E., (1975). Determining the Characteristics of the Socially Conscious Consumer. Journal of Consumer Research, 2, 188-196. 